\title{
Therapeutic Implications of the Hyperglutamatergic Effects of NMDA Antagonists
}

John H. Krystal, M.D., Aysenil Belger, Ph.D., D. Cyril D'Souza, Amit Anand, M.D., Dennis S. Charney, M.D., George K. Aghajanian, M.D., and Bita Moghaddam, Ph.D.

Antagonists of the N-methyl-D-aspartate (NMDA) subtype of glutamate receptor produce transient effects in healthy human subjects that resemble symptoms observed in some schizophrenic patients. NMDA antagonists also impair aspects of human corticolimbic information processing in a fashion that resembles deficits associated with schizophrenia, as measured by electrophysiologic and functional neuroimaging paradigms. Although all current antipsychotics block dopamine- $2\left(D_{2}\right)$ receptors, recent studies question the centrality of $D_{2}$-receptor stimulation to the NMDA-antagonist psychosis. For example, pretreatment with haloperidol fails to attenuate the psychotic effects of ketamine in healthy human subjects. Also, pretreatment with amphetamine fails to increase these effects of ketamine. Both preclinical and clinical studies suggest that subanesthetic doses of NMDA antagonists activate glutamate neurons in the cerebral cortex and hippocampus.
Recent preclinical and clinical studies also suggest that drugs that attenuate glutamate release, including group II/III metabotropic glutamate-receptor agonists, drugs that block voltage-dependent ion channels, and serotonin- $2 A$ (5-HT ${ }_{2 A}$ )-receptor antagonists may attenuate NMDA antagonist effects. To the extent that NMDA antagonist effects provide insight into the pathophysiology of schizophrenia, these novel pharmacologic strategies and others may provide a rationale for the exploration of new treatments that do not involve $D_{2}$-receptor blockade. If schizophrenia, like NMDA-antagonist effects, involves hyperglutamatergic states, then these novel pharmacotherapeutic strategies also may have neuroprotective or neurotrophic consequences that influence the course of schizophrenia. [Neuropsychopharmacology 22:S143-S157, 1999] (C) 1999 American College of Neuropsychopharmacology. Published by Elseiver Science Inc.
KEY WORDS: Glutamate; NMDA; Ketamine; Schizophrenia; Frontal cortex; Attention; Cognitive function;

Pharmacotherapy; Lamotrigine; Serotonin; 5-HT2A; LY354740; M100907; MDL 100,907

From the Department of Psychiatry (JHK, AB, DCD, AA, DSC, GKA, BM), Yale University School of Medicine, New Haven, Connecticut; Psychiatry Service (JHK, AB, DCD, AA, DSC, GKA, BM), VA Connecticut Healthcare System, West Haven, Connecticut: Abraham Ribicoff Research Facilities (JHK, DSC, GKA, BM), Connecticut Mental Health Center, New Haven, Connecticut, USA.

Address correspondence to: John H. Krystal, M.D., Psychiatry Service (116-A), VA Connecticut Healthcare System, 950 Campbell Avenue, West Haven, CT 06516. Tel.: 203-937-4790. Fax: 203-9373468. E-mail: john.krystal@yale.edu

Received June 24, 1999; accepted August 2, 1999.
The field of schizophrenia research is rapidly moving from a focus on the contributions of single neurotransmitters or brain regions toward an appreciation of the interactions of multiple neurotransmitter systems, neural networks, and intracellular mechanisms (Aghajanian and Marek 1999; Carlsson et al. 1997; Krystal et al. 1999b). Investigators are abandoning oversimplified dopaminergic models suggesting that all activation is detrimental to symptoms in schizophrenic patients. Instead, optimal levels of stimulation of particular dopamine-receptor subtypes are needed to sustain behavior and higher cognitive functions (Arnsten 1997; Goldman-Rakic and Selemon 1997). Concurrently, psychiatric researchers are assimilating both the promise and 
shortcomings of both typical and atypical neuroleptics (Meltzer 1997). As a result, it is now timely to consider the possibility that the next era in medications development for treating schizophrenia will involve mechanisms other than dopamine-2 $\left(\mathrm{D}_{2}\right)$-receptor antagonism.

This review highlights a novel perspective on the neurobiology and treatment of schizophrenia growing from the study of the effects of the N-methyl-D-aspartate (NMDA) glutamate-receptor antagonists in animals and humans. It considers parallels between the transient symptomatic effects of single doses of NMDA antagonists in healthy human subjects and findings in schizophrenic patients. It then highlights similarities between disturbances in information processing produced by NMDA antagonists and deficits observed in schizophrenic patients. Next, this review attempts to provide some insights into mechanisms that link NMDA-receptor antagonism to glutamatergic activation and information-processing deficits. This review then summarizes evidence that dopaminergic systems have limited contributions to positive and negative symptoms produced by NMDA antagonists. Finally, it considers the utility of facilitation of the glycine-B site of the NMDA-receptor complex and drugs that attenuate glutamate release as pharmacotherapies for schizophrenia based on their capacity to attenuate the effects of NMDA antagonists in animals and humans. Because glutamate has both neurotrophic and neurotoxic effects in the brain, potential implications of glutamatergic pharmacotherapies for the course of schizophrenia is considered.

\section{PARALLELS BETWEEN NMDA-ANTAGONIST EFFECTS IN HEALTHY SUBJECTS AND SCHIZOPHRENIC PATIENTS}

Luby and his colleagues coined the term "schizophrenomimetic" to describe the striking similarities between the effects of phencyclidine (PCP), and the symptoms of schizophrenia (Luby et al. 1959). The identification of NMDA-receptor antagonism as the mechanism of action of $\mathrm{PCP}$, the implication of NMDA receptors in many fundamental aspects of neural plasticity and neurotoxicity, and reports of altered glutamate-receptor binding in postmortem tissue from schizophrenic patients rekindled interest in the effects of PCP (Anis et al. 1983; Krystal et al. 1999b; Madison et al. 1991; Rothman and Olney 1987; Zukin and Zukin 1979). Although ethical considerations prohibited the exploration of PCP effects in humans, its derivative, ketamine, was a widely used anesthetic agent approved by the United States Food and Drug Administration with an established and extensive record of safety in healthy humans (Domino et al. 1965; Green and Johnson 1990; Haas and Harper
1992; Reich and Silvay 1989; White et al. 1982). Building on this foundation, a series of rigorous psychopharmacological studies, using validated measures for assessing the signs and symptoms of schizophrenia, were initiated that documented the cognitive and behavioral effects of ketamine in healthy human subjects (Krystal et al. 1994a; Malhotra et al. 1996; Newcomer et al. 1999).

As noted in Table 1, the new generation of studies suggested that subanesthetic ketamine doses produced three clusters of symptoms in healthy subjects that have been described in schizophrenic patients: positive, negative, and disorganization symptoms (Andreasen et al. 1995; Liddle and Morris 1991). The extent to which ketamine produces these effects is related to the dose and rate of infusion (Krystal et al. 1994a; Newcomer et al. 1999). The positive symptoms produced by ketamine included grandiose and paranoid delusions, bizarre ideation, profound perceptual alterations, and, less frequently, hallucinations. In some subjects, the positive symptoms produced by ketamine are indistinguishable from symptoms seen in schizophrenic patients (Krystal et al. 1999a). However, the positive symptoms produced by ketamine also show differences from symptoms seen in schizophrenia. For example, auditory hallucina-

Table 1. Similarity and Dissimilarity of Ketamine Effects in Healthy Human Subjects to Signs and Symptoms of Schizophrenia

\begin{tabular}{|c|c|}
\hline Positive symptoms & $\begin{array}{l}\text { - Delusions } \\
\text { - Perceptual alterations/ } \\
\text { hallucinations }\end{array}$ \\
\hline Negative symptoms & $\begin{array}{l}\text { - Blunted affect } \\
\text { - Emotional withdrawal }\end{array}$ \\
\hline Disorganization symptons & $\begin{array}{l}\text { - Loose associations } \\
\text { - Tangentiality } \\
\text { - Thought blocking } \\
\text { - Perseveration } \\
\text { - Disorganized behavior }\end{array}$ \\
\hline $\begin{array}{l}\text { Cognitive deficits associated } \\
\text { with frontal cortical ciruits }\end{array}$ & $\begin{array}{l}\text { - Distractibility } \\
\text { - Reduced verbal fluency } \\
\text { - Concreteness of thought } \\
\text { - Impairments in planning } \\
\text { - Working memory deficits } \\
\text { - Impairment of smooth } \\
\text { pursuit eye-tracking } \\
\text { - Reduced cortical activation } \\
\text { while performing the } \\
\text { oddball task }\end{array}$ \\
\hline $\begin{array}{l}\text { Cognitive deficits associated } \\
\text { with temporohippocampal } \\
\text { circuits }\end{array}$ & $\begin{array}{l}\text { - Disruption of new learning } \\
\text { - Reduced prepulse inhibition } \\
\text { of the startle response }\end{array}$ \\
\hline Mood effects & $\begin{array}{l}\text { - Euphoria } \\
\text { - Anxiolysis (low-dose) } \\
\text { - Anxiety (high-dose) }\end{array}$ \\
\hline Other perceptual effects & $\begin{array}{l}\text { - Distortion in body } \\
\text { perception } \\
\text { - Distortion of time perception }\end{array}$ \\
\hline
\end{tabular}


tions are produced infrequently by ketamine. Also, perceptual alterations that more closely resemble dissociative states are a prominent behavioral effect of ketamine (Krystal et al. 1995). Clinical experience with NMDA antagonists in environments with varying levels of visual and auditory stimulation suggests that the degree to which NMDA antagonists produce symptoms within a given sensory domain (e.g., visual, auditory) is related to the extent of environmental stimulation within that sensory domain (Krystal et al. 1999a; Krystal et al. 1998a). Thus, dose, pharmacokinetic issues, and environmental manipulations may influence the degree to which ketamine effects seem similar to the positive symptoms of schizophrenia.

The interpretation of negative symptoms produced by ketamine in healthy individuals is also complicated. Ketamine-induced negative symptoms include blunted affect, emotional withdrawal, and psychomotor retardation. Negative symptoms produced by ketamine may be confounded by the sedative effects of this drug. For example, premedication with two sedating medications, lorazepam $2 \mathrm{mg}$ or clozapine $25 \mathrm{mg}$, increased negative symptoms produced by ketamine in healthy human subjects (Krystal et al. 1998b; Lipschitz et al. 1997). However, at similarly sedating doses, ketamine clearly produced more negative symptoms than both lorazepam and haloperidol (Krystal et al. 1999d; Krystal et al. 1998b). Also, negative symptoms in schizophrenic patients have been divided into primary symptoms intrinsic to the disorder, and secondary symptoms arising as a consequence of state-related changes or factors extrinsic to the pathophysiology of schizophrenia, such as extrapyramidal symptoms (Carpenter et al. 1988). Ketamine produces bradykinesia in healthy human subjects, and this action may contribute to the induction of secondary negative symptoms (Krystal et al. 1999d).

In healthy subjects, ketamine produces cognitive impairment and behavioral disorganization in healthy subjects that resemble those seen in some schizophrenic patients. Two studies found that subanesthetic ketamine produced thought disorder in healthy subjects as measured by Gorham's proverb test (Krystal et al. 1999d; Krystal et al. 1998b). After ketamine administration, thought processes become concrete and overpersonalized. Loose associations, tangentiality, perseveration, and thought blocking are also common. Recently, ketamine-induced thought disorder in healthy subjects proved to be essentially indistinguishable from thought disorder in a group of schizophrenic patients (Adler et al. 1998).

Other cognitive impairments produced by ketamine also resemble those associated with schizophrenia. Ketamine impairs performance on several cognitive tests associated with the frontal cortex including verbal fluency and the Wisconsin Card Sorting Test (WCST) (Krystal et al. 1999d; Krystal et al. 1998b; Krystal et al. 1994b). Ketamine preferentially interferes with learning the abstract matching rules on the WCST and relatively spares performance on this test once matching rules are learned (Krystal et al. 1999c). This finding challenges the view that subanesthetic doses of ketamine produce diffuse cognitive impairment or delerium. Ketamine also produces encoding deficits in tests of working memory and short-term memory (Ghoneim et al. 1985; Krystal et al. 1994a; Malhotra et al. 1996; Newcomer et al. 1999; Øye et al. 1992).

Recent interest in chronic or intermittent (binge related) NMDA-antagonist effects as models for the pathophysiology of schizophrenia has not been paralleled by informative clinical trials (Jentsch and Roth 1999). Interest in chronic NMDA-antagonist administration stems, in part, from the suspicion that protracted psychoses observed in association with the abuse of NMDA antagonists in nonpsychotic populations reflect a characteristic of chronic or repeated intermittent administration of NMDA antagonists (Allen and Young 1978; Fauman et al. 1976). However, these naturalistic studies are quite problematic to interpret for a number of reasons: (1) it is not clear whether chronic psychosis in this population reflects a preexisting predisposition for psychosis; (2) NMDA antagonists, when abused, are frequently intermixed with other propsychotic substances, resulting in a confusing admixture of effects; (3) individuals may be misled regarding the actual composition of street drugs called PCP or ketamine; and (4) there may be a bias to attribute psychoses emerging in people with a history of PCP use to ingestion of that drug. To date, there are no laboratory-based psychopharmacologic studies of healthy populations administered ketamine or PCP on a chronic basis. Ketamine does not seem to produce a schizophrenia-like syndrome when administered chronically to treat chronic pain (Krystal et al. 1999e). However, these studies were not designed to evaluate the impact of ketamine binges. Furthermore, chronic administration of the NMDA antagonist, amantidine, seems to be relatively well-tolerated by most schizophrenic patients (Di Mascio et al. 1976; Flaherty and Bellur 1981; Konig et al. 1996). Thus, it is premature to conclude that chronic NMDA-antagonist administration is superior to acute NMDA-antagonist administration in modeling the signs and symptoms of schizophrenia.

In summary, there are many clinical parallels between the acute effects of ketamine or PCP and the phenomenology of schizophrenia. However, ketamine effects in healthy human subjects are not identical to schizophrenia. It is not yet clear whether the differences between NMDA antagonist effects and schizophrenia reflect a substantial impediment for using NMDA antagonist effects to gain insights into the pathophysiology or treatment of schizophrenia. However, caution is clearly justified in this regard. As has been suggested 
previously (Abi-Saab et al. 1998), a cautious first step may be to determine those elements of acute or chronic ketamine response that are relevant to schizophrenia.

\section{Similarities in Information-Processing Deficits Associated with Schizophrenia and Ketamine Administration in Healthy Human Subjects}

The neurobiological substrates for cognitive deficits in schizophrenia are of great interest at a time when developing novel treatments targeting these deficits has emerged as a priority. Schizophrenic patients are impaired in their capacity to attend to important or salient information and to ignore irrelevant or distracting information in the environment. Behavioral studies show that attention deficits precede the onset of schizophrenia and predict the development of symptoms in individuals at high risk for developing this disorder (Freedman et al. 1998).

Electrophysiologic studies have helped to establish the view that attention dysfunction in schizophrenia reflects disturbances at several levels within corticolimbic networks (Boutros et al. 1999). Two techniques, in particular, have been used to suggest that patients have impairments in inhibiting their response to sensory input. For example, when presented with pairs of clicks, schizophrenic patients do not show a normal suppression of the midlatency evoked response (P50), an action that may involve the hippocampus (Freedman et al. 1996). Similarly, schizophrenic patients show a reduced capacity to inhibit their startle response to a loud noise (pulse) that is preceeded by a brief quiet noise (prepulse) (Braff et al. 1978). Prepulse inhibition (PPI) of the startle response has an increasingly well-defined corticolimbic circuitry (Swerdlow and Geyer 1998). PPI deficits in schizophrenic patients seem to be related to inefficiency in response selection related to the failure to ignore distracting environmental information (Karper et al. 1996).

Convergent electrophysiologic and functional neuroimaging findings provide support for the view that frontal cortical activation deficits in schizophrenic patients are related to disruption of the processing of important environmental information. For example, novelty is a key element related to the salience of environmental stimuli. Normally, when stimuli are presented repeatedly, the subject habituates to their presentation and ignores their presence. However, when a novel stimulus appears among the background stimuli, that is, an "oddball," the subject focuses attention on the novel stimulus. In this "oddball paradigm," presentations of novel stimuli elicit a characteristic electrophysiologic signal, the P300. Schizophrenic patients show reductions in the amplitude and latency of the P300 response that are related to attention deficits (Grillon et al. 1990) and the presence of particular symptoms (Belger, unpublished data). Similarly, schizophrenic patients show reduced dorsolateral prefrontal cortex (middle frontal gyrus) and anterior cingulate cortex activity, but preserved parieto-occipital cortex activation while performing a visual oddball task, as assessed using functional magnetic resonance imaging (fMRI) (Belger et al. 1997).

Recent studies suggest that in healthy subjects ketamine produces a similar pattern of information processing deficits that is similar to the pattern in schizophrenic patients. It impairs the ability to both effectively gate the processing of sensory stimuli and process salient stimuli. For example, ketamine increases distractibility (Krystal et al. 1999d; Krystal et al. 1998b) and it may depress startle PPI (Krystal et al. 1999f) in healthy humans. Furthermore, ketamine reduces the activation of the dorsolateral prefrontal cortex and anterior cingulate cortex, but not parietal cortex, during the performance of the oddball task, as assessed with event-related fMRI (Krystal et al. 1998b). Reductions in cortical activation during the oddball task are consistent with ketamine-induced reductions in P300 amplitude in healthy subjects (Umbricht et al. 1999). In this study, ketamine effects on N200 and N100 were less prominent than its effects on P300. This differential effect is consistent with the fMRI study in suggesting that subanesthetic ketamine preferentially interferes with the frontal "executive" control of information processing relative to its effects on regions engaged at earlier stages of information processing.

As noted earlier, the drive to develop effective pharmacotherapies for information-processing deficits in schizophrenic patients places a premium on the rational development of pharmacotherapies targeting these deficits. This approach will likely depend on the generation of accurate pathophysiological hypotheses. In the next sections, mechanisms that may underlie the similarities between information-processing deficits produced by ketamine and those observed in schizophrenic patients are considered.

\section{Hyperglutamatergic Consequences of Subanesthetic NMDA-Receptor Antagonism, Circuit Dysfunction, and Schizophrenia}

The ability of NMDA antagonists to block an excitatory glutamate-receptor subclass suggested that these drugs represented a model for functional deficits in cortical glutamate systems (Carlsson and Carlsson 1990; Javitt and Zukin 1991). Furthermore, several preclinical paradigms have clearly demonstrated that NMDA-receptor antagonists block a component of glutamatergic neuronal excitation and neurotoxicity mediated by stimulation of this glutamate receptor subclass (Anis et al. 1983; Krystal et al. 1999e; Rothman and Olney 1987).

Consistent with the cognitive effects of NMDA antagonists, the excitatory actions of NMDA receptors 
have an associative function stemming from the fact that they are both ligand-gated and voltage dependent (Figure 1) (Schiller et al. 1998; Yuste et al. 1999). Under basal conditions, magnesium ions act as a noncompetitive antagonist of this receptor; that is, a plug for the calcium channel. When the postsynaptic neuron is activated (partially depolarized), the magnesium plug is displaced, and the combined binding of glutamate and glycine evokes the entry of calcium via the NMDA receptor-coupled channel. This process is associative, because glutamate release by the presynaptic neuron, via NMDA receptors, can serve to amplify the signal generated by another neuronal input; that is, the one that produced the initial partial depolarization of the postsynaptic neuron. This interaction is nicely illustrated at the level of the dendritic spine in layer V cortical pyramidal neurons (Schiller et al. 1998) or hippocampal CA1 pyramidal neurons (Yuste et al. 1999). Dendritic spines are key structures for integrating neuronal input, and NMDA receptors are preferentially localized to these spines (Conti 1997). In the brain slice, presynaptic activation produces a moderate level of calcium entry via voltage-dependent calcium channels, thought to be of the L-, $\mathrm{N}-$, and P-subtypes as well as calcium-permeable
AMPA or kainate receptors (Schiller et al. 1998; Segal 1995; Yuste et al. 1999). When the postsynaptic neuron is stimulated-simulating the convergent excitatory input-the magnesium blockade is displaced, and the same degree of glutamatergic stimulation produces a greatly enhanced calcium entry via the additional contribution of NMDA receptors.

However, there is growing evidence that subanesthetic doses of NMDA-receptor antagonists produce hyperactivity of glutamatergic pyramidal neurons in cortical and limbic regions that results in stimulation of non-NMDA glutamate receptors (Moghaddam et al. 1997; Patel and McCulloch 1995). For example, NMDA antagonists preferentially attenuate the activity of inhibitory interneurons in the hippocampus that mediate feedforward and feedback inhibition, resulting in increased spiking by pyramidal neurons (Grunze et al. 1996). Furthermore, this study showed that NMDA antagonists more potently block the long-term potentiation (LTP) of inhibitory neurons than of pyramidal neurons. Similarly, as presented in Figure 2, subanesthetic doses of NMDA antagonists stimulate glutamate release in the prefrontal cortex when administered systemically (Moghaddam et al. 1997; Moghaddam and

\section{Presynaptic (Axon)}


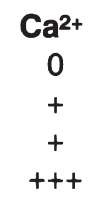

\section{Postsynaptic (Dendrite)}
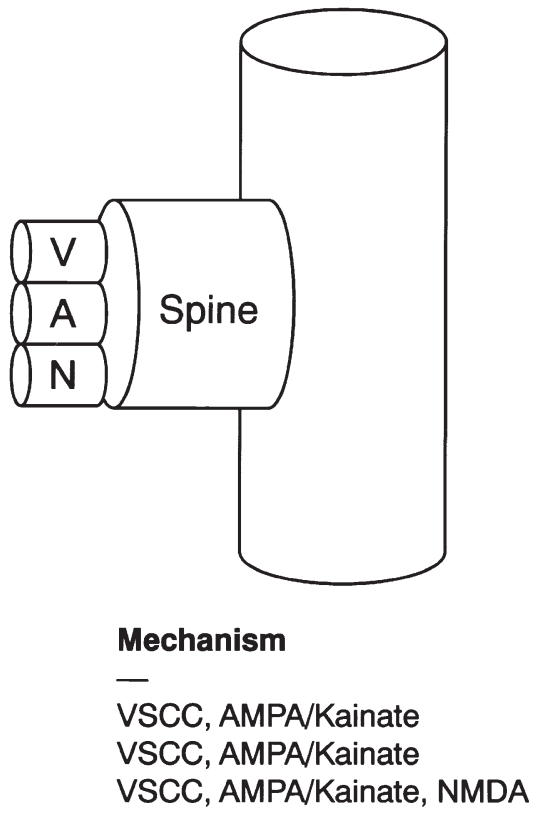

Figure 1. This figure illustrates the modulatory associative function of NMDA receptors in dendritic spines. Dendritic spines are key structures that permit neurons to integrate inputs. Excitatory input to the presynaptic and postsynaptic neurons via non-NMDA mechanisms is not associative. Therefore, release of glutamate from the presynaptic neuron or stimulation of the postsynaptic neuron produces calcium influx through a variety of mechanisms, including voltage-sensitive calcium channels (VSCC) and calcium-fluxing AMPA and kainate receptors. It is only when both the presynaptic neuron and postsynaptic neuron are simultaneously activated that the magnesium block is displaced from the NMDA-receptor channel, and glutamate release recruits NMDA receptors. Thus, NMDA-receptor stimulation serves to enhance synaptic function at synapses where there is convergent activating input. This type of convergent activation is essential for many forms of neural plasticity involving NMDA receptors, including long-term potentiation (from Schiller et al. 1998; Yuste et al. 1999). 
Adams 1998). As with the hippocampus, reductions in GABAergic interneuron activity may contribute to enhanced glutamate release in this region (Olney and Farber 1995b). This view is supported by preliminary data suggesting that local injection of NMDA antagonists into the prefrontal cortex enhance glutamate release in this region (Moghaddam, personal communication).

However, other mechanisms may also contribute to the hyperglutamatergic effects of NMDA antagonists. For example, disinhibition of glutamate neurons would be predicted to produce feedforward activation via local projections (Lubke et al. 1996) and through projections to other brain regions that send excitatory projections to the cortex, including the thalamus and amygala (Groenewegen et al. 1997). Furthermore, systemic administration of NMDA antagonists facilitates raphe neuronal activity and serotonin release in the cortex (Jentsch et al. 1997; Lejeune et al. 1994; Lindefors et al. 1997). In turn, serotonin-2A (5- $\left.\mathrm{HT}_{2 \mathrm{~A}}\right)$-receptor stimulation activates prefrontal cortical pyramidal neurons in layer $\mathrm{V}$ via $5-\mathrm{HT}_{2 \mathrm{~A}}$ receptors located on their apical dendrites (Aghajanian and Marek 1997; Jakab and Goldman-Rakic 1998).

\section{Normal Conditions}

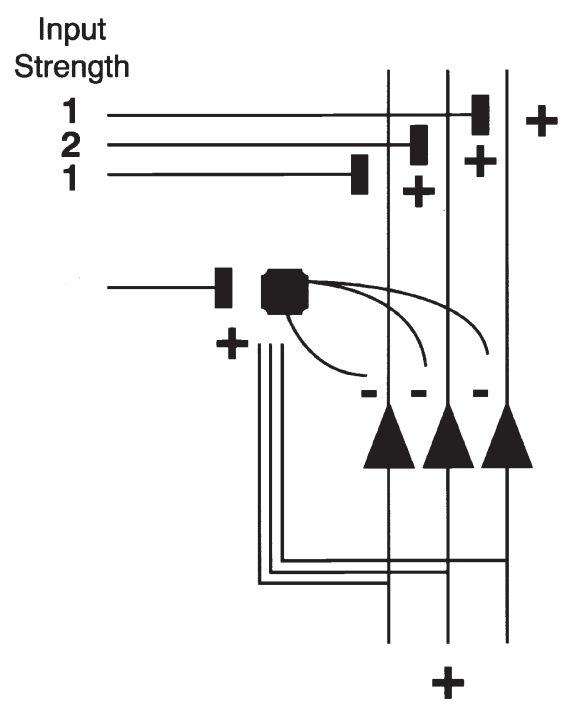

Cerebral metabolic studies in both rodents and humans support the view that subanesthetic doses of NMDA antagonists produce regional cortical metabolic activation. For example, several studies suggest that cortical glucose metabolism is increased regionally in animals administered NMDA antagonists (Clow et al. 1991; Kurumaji and McCulloch 1990; Nehls et al. 1988; Tamminga et al. 1987). Similarly, ketamine increases frontal cortex cerebral blood flow and glucose metabolism in healthy human subjects (Breier et al. 1997) and schizophrenic patients (Lahti et al. 1995a). Linking glutamate to these metabolic findings, changes in cortical glucose metabolism are closely associated with parallel changes in cortical glutamatergic neurotransmission (Magistretti and Pellerin 1997; Sibson et al. 1997; Sibson et al. 1998).

Neural network modeling studies may be helpful in resolving the seeming paradox that NMDA-receptor antagonists activate prefrontal cortex metabolism and yet impair information-processing functions associated with the prefrontal cortex and hippocampus. A simplified introduction to this hypothesis is presented below. It is assumed that functional output from cortical networks is generated when pyramidal neurons reach a

\section{NMDA-Antagonist Effect}

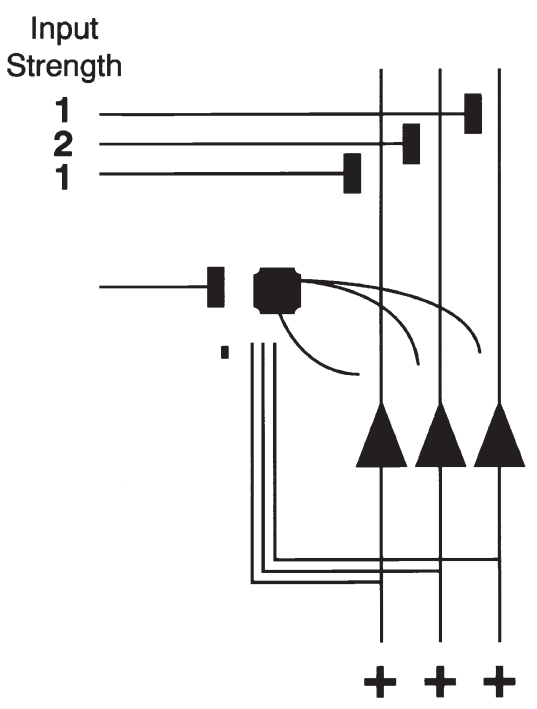

Figure 2. This simplified schematic illustrates mechanisms through which NMDA antagonists might produce loss of functional selectivity and glutamatergic hyperactivity within a cortical or hippocampal network. The left figure illustrates the normal function of this imaginary circuit. Excitatory glutamatergic cortico-cortico or thalamo-cortical inputs (terminals with " + " sign) make contact with pyramidal neurons (triangle) or GABA interneuron (octagon). These synapses involve NMDA and other excitatory receptors as illustrated in Figure 1. In addition, there is feedforward inhibition of pyramidal neurons mediated by glutamatergic excitation of interneurons. As a result, when there is selectivity in the strength of inputs to particular neurons (represented as a stronger input to the middle neuron), the result is a selective and proportionate glutamatergic activation (represented as the selective activation of the middle pyramidal neuron). The right figure illustrates the impact of NMDA antagonists. This figure highlights changes from the left figure and therefore redundant information is omitted to achieve clarity. Low doses of NMDA antagonists attenuate the activation of interneurons resulting in disinhibition of all three pyramidal neurons. As a result, the functional specificity of the inputs of graded intensity is lost as all neurons are activated. Thus, NMDA antagonists produce glutamatergic hyperactivity that may be dysfunctional (modified from Lisman et al 1998; see also Grunze et al. 1996; Aghajanian and Marek 1999, Williams and Goldman-Rakic, personal communication). 
threshold of activation that produces an informationbearing signal. Similarly, it is critical to avoid the activation of extraneous neurons and to terminate the activation of task-related neurons appropriately in order to minimize interference or "noise."

NMDA-receptor antagonists seem to disrupt the capacity of cortical networks to process information efficiently, because they interfere with the spatial (i.e., the number of activated neurons) and temporal selectivity of task-related cortical pyramidal activation (Figure 2) (Grunze et al. 1996; Lisman et al. 1998). As noted earlier, the associative functions of the NMDA receptor seem to depend on the convergence of glutamatergic neuronal inputs. The timing, amplitude, and number of convergent inputs is modulated by an extraordinary diversity of extrinsic modulatory inputs including monoamine systems (Goldman-Rakic et al. 1990) and thalamocortical glutamatergic projections (Carlsson et al. 1997). Also, within a particular cortical region, local circuits involving the interplay of glutamatergic and GABAergic neurons are critically important for maintaining the optimum capacity to process information (Wilson et al. 1994). The integrity of the interplay of these multiple mechanisms is reflected by several indices including high-frequency electrical activity $(40 \mathrm{~Hz})$ (Wang and Buzsaki 1996).

The seeming paradox that subanesthetic ketamine activates prefrontal cortex metabolism and yet substantially blunts the cognitive activation of this region may reflect the disruption of inhibitory neurotransmission by subanesthetic ketamine. Both in the hippocampus and in the cerebral cortex, low-dose NMDA antagonists may preferentially disrupt feedforward and feedback activation of GABAergic interneurons (Grunze et al. 1998; Lisman et al. 1998). These models predict that disinhibition produces a loss of adaptive functional modulation or "tuning" of glutamatergic activity within a region. In other words, deficits in NMDA-receptor function produce an inappropriate recruitment of additional neurons, may extend the duration of activation, may cause disproportionate (abnormally large or small) magnitude of activation to the input, and reduced capacity to terminate one response to process the next input. The consequence of NMDA-mediated disruptions within local circuits may be loss of region-specific associative functions, such as "stimulus-binding" in the hippocampus or working memory in the prefrontal cortex (Grunze et al. 1998; Lisman et al. 1998).

A network-based view of NMDA-antagonist effects may have important implications for the so-called "NMDA-antagonist model of schizophrenia." First, it suggests that NMDA-antagonist effects may resemble cortical dysfunction associated with schizophrenia, because both conditions are associated with similar impairments in the information-processing capacity of cortical circuits. However, several neural network models
(Grossberg 1984; Lisman et al. 1998) predict that hypoglutamatergic states (reduced glutamatergic signal or excessive inhibition) and hyperglutamatergic states (inhibitory deficits or heightened activation) could seem to produce similar disruptions in information processing. Thus, the fact that ketamine and schizophrenia are associated with similar physiological and behavioral output abnormalities (i.e., signs and symptoms) does not necessarily imply that schizophrenia is also a hyperglutamatergic state.

In fact, the literature describing cortical metabolic changes in schizophrenia contains conflicting findings. The finding of metabolic hypofrontality in schizophrenic patients in some positron emission tomography flurodeoxyglucose (PET-FDG) studies would tend to favor a hypoglutamatergic model (Buchsbaum et al. 1992; Tamminga et al. 1992). However, PET-FDG of resting metabolism in schizophrenic patients have been inconsistent in their findings (Weinberger and Berman 1996). PET-FDG and [1H]-MRS studies also have provided direct or suggestive evidence of a prefrontal hypermetabolic and hyperglutamatergic pathological process in schizophrenia (Bartha et al. 1997; Cleghorn et al. 1989). Furthermore, even when a group of patients shows depressed frontal metabolic activity, psychotic symptoms are frequently associated with increases in metabolism (Cleghorn et al. 1990; Tamminga et al. 1992). For the latter studies, the combination of hypermetabolism and cognitive activation deficit supports the model growing from effects of NMDA antagonists on the function of cortical circuits. If all of these studies are valid, the clinical literature suggests at least two possible interpretations: (1) schizophrenic patients, are more variable in their glutamatergic regulation than controls; that is, some patients are hypoglutamatergic and others are hyperglutamatergic; or (2) individual patients have deficits in their capacity to "tune" their cortical glutamatergic function optimally and, therefore, they seem to be hypoglutamatergic or hyperglutamatergic, depending upon state-related factors. The latter possibility is attractive, because it may highlight the potential role of GABA, monoaminergic, and neuropeptide systems in optimizing cortical information processing (Aghajanian and Marek 1999; Arnsten 1997; Jakab et al. 1997; Williams and Goldman-Rakic 1995; Wilson et al. 1994).

Cortical disturbances in schizophrenic patients may or may not be related to changes in NMDA receptors. For example, there may be functional similarities between deficient cortical feedback inhibition predicted to exist in schizophrenia on the basis of postmortem evidence (Akbarian et al. 1993; Akbarian et al. 1995; Benes et al. 1991; Woo et al. 1998) and the disinhibiting effects of NMDA antagonists. Second, in schizophrenic patients, many distinct neurobiological abnormalities could produce convergent functional disturbances in cortical networks. Thus, circuit models would not be inconsis- 
tent with the existence of heterogeneity in the etiology or pathophysiology of schizophrenic patients. Third, if schizophrenia is associated with NMDA-antagonistlike disturbances in the function of cortical networks and not actual deficits in NMDA-receptor function, then putative pharmacotherapies growing out of the NMDA antagonist model may or may not apply to the treatment of schizophrenia. Thus, candidate therapies growing out of this model will need validation in treatment studies conducted in patients.

\section{THE ROLE OF DOPAMINE IN THE} NMDA-ANTAGONIST MODEL OF PSYCHOSIS: IMPLICATIONS FOR THE RELEVANCE OF NMDA ANTAGONISTS TO SCHIZOPHRENIA

To date, no compelling clinical data implicate dopamine in the positive or negative symptoms produced by NMDA antagonists in healthy subjects or schizophrenic patients. Studies of animal behavior question the centrality of NMDA-antagonist effects on dopamine systems to many of the behavioral effects of these drugs (Carlezon and Wise 1996; Carlsson et al. 1997; Keith et al. 1991). In healthy subjects, acute pretreatment with $5 \mathrm{mg}$ of haloperidol, $25 \mathrm{mg}$ of clozapine, and $5 \mathrm{mg}$ of olanzepine did not significantly reduce positive or negative symptoms produced by NMDA antagonists (Krystal et al. 1999b; Lipschitz et al. 1997). The findings with typical neuroleptics in healthy subjects are consistent with the view that chronic treatment with typical neuroleptics is ineffective in reducing the effects of ketamine in schizophrenic patients (Lahti et al. 1995b; Malhotra et al. 1997). However, chronic treatment with atypical neuroleptics may be superior to typical neuroleptics in blocking ketamine effects, although they are still quite limited in this regard (Malhotra et al. 1997).

Consistent with preclinical studies (Verma and Moghaddam 1996), haloperidol pretreatment prevented ketamine-induced deficits in higher cortical functions in healthy human subjects (Krystal et al. 1999b). Although haloperidol and ketamine produced additive impairments in attention, haloperidol pretreatment attenuated the impairments in abstract reasoning, as measured by proverb interpretation, and abstract problem solving, as measured by the WCST.

Amphetamine pretreatment also failed to exacerbate psychosis or negative symptoms in healthy subjects administered ketamine (Krystal et al. 1998c) although amphetamine seems to increase the stimulatory effect of ketamine on mesostriatal dopamine systems in humans (Kegeles et al. 1999). The observation that amphetamine-sensitive schizophrenic patients show a rapid increase in symptoms during amphetamine infusion made this paradigm potentially more informative than studies of acute haloperidol pretreatment. Haloperidol, when used as an antipsychotic, is generally administered chronically before clinical benefits are observed.

Together, these data question the centrality of dopamine to the positive and negative symptoms associated with the NMDA antagonist psychosis. They may also have implications for the applicability of NMDA antagonist effects for schizophrenia. NMDA antagonists do not produce an amphetamine-sensitive psychosis. Thus, psychotomimetic effects of NMDA antagonists differ from the hyperdopaminergic pathophysiology of patients who respond well to typical neuroleptics. Psychostimulants produce a range of responses from improvement to exacerbation in psychosis in patients (Lieberman et al. 1987a). Those patients who show worsening tend to have greater activation of dopamine systems following amphetamine (Laruelle et al. 1996). The hypothesis that NMDA antagonist effects are most relevant to patients with a poor prognosis when treated with typical neuroleptics is consistent with the symptom profile produced by ketamine in healthy subjects. Rather than producing a pure paranoid state, the prominent but transient negative symptoms, thought disorder, and cognitive deficits associated with ketamine administration may have greatest relevance to "nonparanoid" patients who exhibit prominent levels of symptoms and cognitive deficits in a spectrum of symptomatic and functional domains (Carpenter et al. 1988; Keefe et al. 1996).

However, clinical research has made little progress to date in studying the potential unique contributions of non- $\mathrm{D}_{2}$-dopamine receptors to the cognitive and behavioral effects of NMDA antagonists. Clearly, $D_{1} / D_{5}$ receptors play important modulatory roles in local cortical circuits in the prefrontal cortex (Williams and Goldman-Rakic 1995). A role for $D_{1} / D_{5}$-dopamine receptors in modulating ketamine effects may be consistent with the fact that both haloperiodol, which blocks $\mathrm{D}_{2} / \mathrm{D}_{4}$ receptors (Lévesque et al. 1992; Van Tol et al. 1991), and amphetamine, which causes the stimulation of all dopamine receptors, reduce aspects of the behavioral effects of ketamine. Thus, the contributions of $D_{1} / D_{5}$ receptors to the behavioral effects of ketamine and the signs and symptoms of schizophrenia remain of scientific and clinical interest.

\section{THERAPEUTIC IMPLICATIONS OF THE HYPERGLUTAMATERGIC EFFECTS OF NMDA ANTAGONISTS}

This review highlighted several actions associated with subanesthetic doses of NMDA antagonists: reduction in NMDA-receptor function, distribution of pyramidal neurons, and loss of functional regulation of activity of pyramidal neurons. Each of these perspectives suggests 
novel pharmacologic approaches that might be evaluated in schizophrenic patients.

The strategy of enhancing NMDA-receptor function by augmenting treatment with an agonist of the glycine-B coagonist site of the NMDA receptor has received the greatest study to date. One preliminary report suggests that intravenous glycine infusion, at doses that raise human cerebrospinal fluid levels by up to fourfold, attenuates some behavioral effects of ketamine in healthy human subjects (D'Souza et al. 1997). This finding is consistent with evidence that chronic administration of very high oral doses of glycine and low doses of the partial agonist D-cycloserine may produce reduction in negative symptoms, improvement in mood, and improvement in attention and problemsolving (Goff et al. 1995, 1999; Heresco-Levy et al. 1999; Javitt et al. 1994; Leiderman et al. 1996). Recently, promising data were published regarding the addition of D-serine to neuroleptics (Tsai et al. 1998). These data suggest that enhancement of NMDA-receptor function may produce benefits in schizophrenic patients. However, for unclear reasons, benefits of glycine-B agonists may not be observed when added to clozapine (Goff et al. 1996). There is also great interest in studying the clinical efficacy of glycine transporter antagonists in human laboratory paradigms and treatment of schizophrenic patients (Javitt et al. 1997).

A second pharmacologic strategy growing from the effects of NMDA antagonists is to attenuate "hyperglutamatergic" states by drugs acting at metabotropic glutamate receptors or voltage-dependent ion channels. A preclinical study found that LY354740, an agonist at group II/III metabotropic-glutamate receptors (mGluR II/III), attenuated PCP-stimulated enhancement of prefrontal cortex glutamate release and cognitive impairments in rats (Moghaddam and Adams 1998). Future studies will evaluate LY354740 in schizophrenic patients and in the human ketamine "model." Another approach has been to study the anticonvulsant, lamotrigine. Lamotrigine attenuates some forms of cortical glutamate release via inhibition of sodium channels, P- and $\mathrm{N}$-type calcium channels, and potassium channels (Grunze et al. 1998; Stefani et al. 1996; Waldmeier et al. 1996; Wang et al. 1996). Given the interaction of P- and N-type calcium channels with NMDA receptors in cortical dendritic spines (Schiller et al. 1998), the interactive effects of lamotrigine and ketamine were of interest. In humans, lamotrigine attenuated the perceptual, psychotic, and amnestic effects of ketamine in healthy human subjects (Anand et al. 1997). The ability of LY354740 and lamotrigine to attenuate cognitive deficits highlights the importance of appreciating the nuances of local circuit regulation. Drugs that prevent inappropriate (i.e., abnormal neuronal recruitment or loss of the optimal temporal features of activity) or excessive glutamate release may restore cognitive dysfunction al- though maintenance of normal glutamatergic function will be required to sustain cognition and behavior.

Drugs that optimize extrinsic inputs to local cortical circuits also could restore normal function. In this regard, selective 5- $\mathrm{HT}_{2 \mathrm{~A}}$-receptor antagonists are of interest. In rat PPI studies, selective $5-\mathrm{HT}_{2 \mathrm{~A}}$ antagonists and atypical neuroleptics with potent $5-\mathrm{HT}_{2 \mathrm{~A}}$ antagonism seem to be more effective than typical neuroleptics in preventing PCP-related disruption of sensory gating (Kehne et al. 1996; Swerdlow and Geyer 1998; Varty et al. 1999). Also, 5- $\mathrm{HT}_{2 \mathrm{~A}}$ antagonists and atypical neuroleptics seem to be more potent than $\mathrm{D}_{2}$ antagonists in blocking the stimulatory effects of NMDA antagonists on locomotor activity and limbic dopaminergic activity (Gleason and Shannon 1997; Martin et al. 1997; Schmidt and Fadayel 1996). Similarly, the possibility that clozapine may be more effective than haloperidol in preventing symptomatic exacerbation in patients administered ketamine draws attention to $5-\mathrm{HT}_{2 \mathrm{~A}}$-receptor mechanisms (Malhotra et al. 1997). It is not yet known whether selective $5-\mathrm{HT}_{2 \mathrm{~A}}$ antagonists reduce ketamine effects in humans. As noted earlier, serotonin and serotonergic hallucinogens activate layer $\mathrm{V}$ cortical glutamate neurons (Aghajanian and Marek 1999). Thus, the capacity to produce innappropriate (i.e., not driven by sensory input) cortical glutamatergic activation is common to both serotonergic hallucinogens and NMDA antagonists (Krystal et al. 1998b). Consistent with this view, stimulatory effects of both serotonergic hallucinogens and PCP on cortical glutamate systems are reduced by the mGluR II/III agonist, LY354740 (Aghajanian and Marek 1999; Moghaddam and Adams 1998). Similarly, a 5- $\mathrm{HT}_{2 \mathrm{~A}}$ antagonist-reversible (M100907) component of the glutamatergic activation produced by NMDA antagonists seems to arise from the capacity of NMDA antagonists to disinhibit raphe neuronal projections to the cortex (Martin et al. 1998). Thus, like mGluR II/III agonists, selective $5-\mathrm{HT}_{2 \mathrm{~A}}$ antagonists may have the capacity to reduce or to "tune" glutamatergic activity. In contrast to the neuroleptic-ketamine interactions cited earlier, unpublished data suggest that low doses of sertindole, which preferentially block $5-\mathrm{HT}_{2 \mathrm{~A}}$ receptors, attenuate the behavioral effects of ketamine in healthy human subjects (F. Vollenweider, unpublished data). There is also suggestive evidence that selective $5-\mathrm{HT}_{2 \mathrm{~A}}$ antagonists, such as M100907 (Offord 1998), or 5- $\mathrm{HT}_{2 \mathrm{~A} / 2 \mathrm{C}}$ antagonists, such as amperozide (Bjork et al. 1992) or ritanserin (Miller et al. 1992; Wiesel et al. 1994) have efficacy in schizophrenic patients.

\section{CLOSING OBSERVATIONS: GLUTAMATE AND THE NATURAL HISTORY OF SCHIZOPHRENIA}

This review highlighted the possibility that one parallel between low-dose NMDA-antagonist effects and the 
pathophysiology of schizophrenia was their association with aberrant function of cortical circuits. Human neuroimaging studies comparing schizophrenic patients and healthy subjects are consistent in suggesting that when performing cognitive tests that activate the prefrontal cortex in healthy subjects, schizophrenic patients show cortical activation deficits (Weinberger and Berman 1996). With regard to the previous discussion, these activation deficits could be consistent with models in which there is a glutamatergic deficit (i.e., no signal) or an inhibitory deficit in local circuit (i.e., no signal above noise).

Glutamatergic hyperactivity and/or deficits in functional activation of glutamatergic neurons related to local and distributed cortical networks may also have consequences for the natural history of schizophrenia. First, a spectrum of developmental abnormalities attributed to disturbances in programmed neural development or the interaction of an aberrant developmental program with environmental insults have been described in adult schizophrenic patients (Raedler et al. 1998). Glutamatergic disturbances, through loss of neurotropic actions of glutamate or exaggeration of neurotoxic effects of glutamate, could contribute to abnormalities in neuronal migration, dendritic regression, synaptic pruning, apoptosis, suppression of ongoing neurogenesis, and the enhancement of other regressive processes in neurodevelopment (Coyle 1996; Gage 1998; Komuro and Rakic 1993; Lipton and Kater 1989; Olney and Farber 1995a; Rakic et al. 1994). Thus, postmortem findings consistent with deficient neural connectivity in schizophrenia could reflect glutamate-related abnormalities in both neurotrophic and neurotoxic functions in development (Rajkowska et al. 1998; Selemon et al. 1998). Environmental stresses (Bagley and Moghaddam 1997), including neurotoxicity associated with viral infection (Fatemi et al. 1998), could contribute to the onset and exacerbation of symptoms via enhancement of cortical and limbic glutamate release or its consequences.

Similarly, there is a disproportionate rate and level of cognitive decline among elderly schizophrenic patients relative to age-matched controls (Davidson et al. 1995). Aging is associated with many regressive neuronal developmental changes, which typically include loss of dendritic arborization in pyramidal neurons in layer V, but not layer IIIc (de Brabander et al. 1998). In one study (Rajkowska et al. 1998), schizophrenic patients showed hypotrophic changes that included involvement of corticocortical projection neurons in layer IIIc. Glutamatergic or other calcium-dependent factors could be involved in the neurotrophic deficits or neurotoxicity described in cortical pyramidal neurons from schizophrenic patients in the period of more pronounced functional decline in late life (Ghosh et al. 1994; Lindefors et al. 1992; Marini et al. 1998).
This developmental view of glutamatergic contributions to schizophrenia raises a number of issues for further study. First, it suggests that pharmacotherapies that attenuate symptoms of schizophrenia by reducing hyperglutamatergic states may also have neuroprotective effects. These neuroprotective effects may be important during the initial development of schizophrenia as well as during the period of exaggerated functional decline in late life. Second, long-term benefits associated with pharmacologic treatments for schizophrenia may include modulation of neurotrophic factors and other intracellular targets. Thus, these targets must be considered increasingly in medications development for schizophrenia. Third, it is possible that the neuroprotective aspects of treatment are unrelated to symptom control and that they must be considered as a distinct component of treatment.

In closing, it is essential to stress that the line of research outlined in this review represents only one of many potential benefits stemming from the safe, cautious, careful, and thoughtful utilization of NMDA antagonists in clinical research. These agents have enabled investigators to study aspects of the functional circuitry of the cerebral cortex. As a result, they provide a potential bridge to novel insights into the pathophysiology and treatment of schizophrenia.

\section{ACKNOWLEDGMENTS}

This review is based on a presentation to the symposium, "Is D2 Antagonism Required for Antipsychotic Activity?" This symposium was sponsored by Hoescht Marion Roussell, Inc. and held in Washington DC, February 17-18, 1999. The authors thank Cameron Carter, M.D., Robert W. Greene, Ph.D., Graham Williams, Ph.D., Patricia Goldman-Rakic, Ph.D., Franz Vollenweider, M.D., and Richard Mohs, Ph.D. for discussions related to elements of the presentation. The work described in this review was supported by funds from the Department of Veterans Affairs to their Merit Review Program, Alcoholism Research Center, Schizophrenia Biological Research Center, and National Center for PTSD. It was also supported by the National Institute of Mental Health through Grants MH-30929 and $\mathrm{MH}-44866$ and by an unrestricted educational grant from Hoechst Marion Roussel. Dr. Krystal received additional funding via an Independent Investigator Award from the National Alliance for Research on Schizophrenia and Affective Disorder, an award from the Patrick and Catherine Weldon Donaghue Medical Research Foundation, and the Civilian Defense and Research Foundation.

\section{REFERENCES}

Abi-Saab W, D'Souza DC, Moghaddam B, Krystal JH (1998): The NMDA antagonist model for schizophrenia: Promises and pitfalls. Pharmacopsychiatry 31:104-109 
Adler CM, Malhotra AK, Goldberg T, Elman I, Pickar D, Breier A (1998): A comparison of ketamine-induced and schizophrenic thought disorder. Society of Biological Psychiatry, Fifty-third Annual Convention, pp 83S-84S

Aghajanian GK, Marek GJ (1997): Serotonin induces excitatory postsynaptic potentials in apical dendrites of neocortical pyramidal cells. Neuropharmacology 36:589-599

Aghajanian GK, Marek GJ (1999): Serotonin model of schizophrenia: Emerging role of glutamate mechanisms. Brain Res Rev, in press

Akbarian S, Bunney WE Jr, Potkin SG, Wigal SB, Hagman JO, Sandman CA, Jones EG (1993): Altered distribution of nicotinamide-adenine dinucleotide phosphate-diaphorase cells in frontal lobe of schizophrenics implies disturbances of cortical development. Arch Gen Psychiat 50:169-177

Akbarian S, Kim JJ, Potkin SG, Hagman JO, Tafazzoli A, Bunney WE Jr, Jones EG (1995): Gene expression for glutamic acid decarboxylase is reduced without loss of neurons in prefrontal cortex of schizophrenics [see comments]. Arch Gen Psychiat 52:258-266; discussion 267-278

Allen RM, Young SJ (1978): Phencyclidine-induced psychosis. Am J Psychiat 135:1081-1084

Anand A, Charney DS, Cappiello A, Berman RM, Oren DA, Krystal JH (1997): Lamotrigine reduces the psychotomimetic-but not the mood elevating - effects of ketamine in humans. Proceedings of the 36th Annual Meeting, American College of Neuropsychopharmacology, p 251

Andreasen NC, Arndt S, Alliger R, Miller D, Flaum M (1995): Symptoms of schizophrenia. Methods, meanings, and mechanisms. Arch Gen Psychiat 52:341-351

Anis NA, Berry SC, Burton NR, Lodge D (1983): The dissociative anaesthetics, ketamine and phencyclidine, selectively reduce excitation of central mammalian neurones by N-methyl-aspartate. Br J Pharmacol 79:565-575

Arnsten AF (1997): Catecholamine regulation of the prefrontal cortex. J Psychopharmacol 11:151-162

Bagley J, Moghaddam B (1997): Temporal dynamics of glutamate efflux in the prefrontal cortex and in the hippocampus following repeated stress: Effects of pretreatment with saline or diazepam. Neuroscience 77:65-73

Bartha R, Williamson PC, Drost DJ, Malla A, Carr TJ, Cortese L, Canaran G, Rylett RJ, Neufeld RW (1997): Measurement of glutamate and glutamine in the medial prefrontal cortex of never-treated schizophrenic patients and healthy controls by proton magnetic resonance spectroscopy. Arch Gen Psychiat 54:959-965

Belger A, Kirino E, McCarthy G, Gore JC, Krystal JH (1997): Assessment of prefrontal activation by infrequent visual targets and nontarget novel stimuli in schizophrenia: A functional MRI study. Proceedings of the 36th Annual Meeting, American College of Neuropsychopharmacology, p 190

Benes FM, McSparren J, Bird ED, San Giovanni JP, Vincent SL (1991): Deficits in small interneurons in prefrontal and cingulate cortices of schizophrenic and schizoaffective patients. Arch Gen Psychiat 48:996-1001

Bjork A, Bergman I, Gustavsson G (1992): Amperozide in the treatment of schizophrenic patients: A preliminary report. In Meltzer HY (ed), Novel Antipsychotic Drugs. New York: Raven, pp 47-58

Boutros N, Belger A, D'Souza DC, Krystal JH (1999): Comparison of four components of sensory gating in schizophrenia and healthy control subjects. Psychiat Res, in press

Braff D, Stone C, Callaway E, Geyer M, Glick I, Bali L (1978): Prestimulus effects on human startle reflex in normals and schizophrenics. Psychophysiology 15:339-343

Breier A, Malhotra AK, Pinals DA, Weisenfeld NI, Pickar D (1997): Association of ketamine-induced psychosis with focal activation of the prefrontal cortex in healthy volunteers. Am J Psychiat 154:805-811

Buchsbaum MS, Haier RJ, Potkin SG, Nuechterlein K, Bracha HS, Katz M, Lohr J, Wu J, Lottenberg S, Jerabek PA, et al. (1992): Frontostriatal disorder of cerebral metabolism in never-medicated schizophrenics. Arch Gen Psychiat 49:935-942

Carlezon WA Jr, Wise RA (1996): Rewarding actions of phencyclidine and related drugs in nucleus accumbens shell and frontal cortex. J Neurosci 16:3112-3122

Carlsson A, Hansson LO, Waters N, Carlsson ML (1997): Neurotransmitter aberrations in schizophrenia: New perspectives and therapeutic implications. Life Sci 61:75-94

Carlsson M, Carlsson A (1990): Interactions between glutamatergic and monoaminergic systems within the basal ganglia-Implications for schizophrenia and Parkinson's disease. TINS 13:272-276

Carpenter WT Jr, Heinrichs DW, Wagman AM (1988): Deficit and nondeficit forms of schizophrenia: The concept. Am J Psychiat 145:578-583

Cleghorn JM, Garnett ES, Nahmias C, Brown GM, Kaplan RD, Szechtman H, Szechtman B, Franco S, Dermer SW, Cook P (1990): Regional brain metabolism during auditory hallucinations in chronic schizophrenia. Br J Psychiat 157:562-570

Cleghorn JM, Garnett ES, Nahmias C, Firnau G, Brown GM, Kaplan R, Szechtman H, Szechtman B (1989): Increased frontal and reduced parietal glucose metabolism in acute untreated schizophrenia. Psychiat Res 28:119-133

Clow DW, Lee SJ, Hammer RP Jr (1991): Competitive (AP7) and non-competitive (MK-801) NMDA receptor antagonists differentially alter glucose utilization in rat cortex. Synapse 7:260-268

Conti F (1997): Localization of NMDA receptors in the cerebral cortex: A schematic overview. Brazil J Med Biol Res 30:555-560

Coyle JT (1996): The glutamatergic dysfunction hypothesis for schizophrenia. Harv Rev Psychiat 3:241-253

D'Souza DC, Gil R, Belger A, Zimmerman L, Tracy L, Larvey K, Cassello K, Krystal J (1997): Glycine-ketamine interactions in healthy humans. Proceedings of the 36th Annual Meeting, American College of Neuropsychopharmacology, p 286

Davidson M, Harvey PD, Powchik P, Parrella M, White L, Knobler HY, Losonczy MF, Keefe R S, Katz S, Frecska E (1995): Severity of symptoms in chronically institutionalized geriatric schizophrenic patients. Am J Psychiat 152:197-207 
de Brabander JM, Kramers RJ, Uylings HB (1998): Layer-specific dendritic regression of pyramidal cells with aging in the human prefrontal cortex. Eur J Neurosci 10:1261-1269

Di Mascio A, Bernardo DL, Greenblatt DJ, Marder JE (1976): A controlled trial of amantadine in drug-induced extrapyramidal disorders. Arch Gen Psychiat 33:599-602

Domino EF, Chodoff P, Corssen G (1965): Pharmacologic effects of CI-581, a new dissociative anesthetic, in man. Clin Pharm Ther 6:279-291

Fatemi SH, Sidwell R, Akhter P, Sedgewick J, Thuras P, Bailey K, Kist D (1998): Human influenza viral infection in utero increases nNOS expression in hippocampi of neonatal mice. Synapse 29:84-88

Fauman B, Aldinger G, Fauman M, Rosen P (1976): Psychiatric sequelae of phencyclidine abuse. Clin Toxicol 9:529-538

Flaherty JA, Bellur SN (1981): Mental side effects of amantadine therapy: Its spectrum and characteristics in a normal population. J Clin Psychiat 42:344-345

Freedman LR, Rock D, Roberts SA, Cornblatt BA, Erlenmeyer-Kimling L (1998): The New York High-Risk Project: Attention, anhedonia, and social outcome. Schizophr Res 30:1-9

Freedman R, Adler LE, Myles-Worsley M, Nagamoto HT, Miller C, Kisley M, McRae K, Cawthra E, Waldo M (1996): Inhibitory gating of an evoked response to repeated auditory stimuli in schizophrenic and normal subjects. Human recordings, computer simulation, and an animal model. Arch Gen Psychiat 53:1114-1121

Gage FH (1998): Stem cells of the central nervous system. Curr Opin Neurobiol 8:671-676

Ghoneim MM, Hinrichs JV, Mewaldt SP, Petersen RC (1985): Ketamine: behavioral effects of subanesthetic doses. J Clin Psychopharmacol 5:70-77

Ghosh A, Carnahan J, Greenberg ME (1994): Requirement for BDNF in activity-dependent survival of cortical neurons. Science 263:1618-1623

Gleason SD, Shannon HE (1997): Blockade of phencyclidineinduced hyperlocomotion by olanzapine, clozapine, and serotonin receptor subtype selective antagonists in mice. Psychopharmacology 129:79-84

Goff DC, Tsai G, Levitt J, Amico E, Manoach D, Schoenfeld DA, Hayden DL, McCarley R, Coyle JT (1999): A placebo-controlled trial of D-cycloserine added to conventional neuroleptics in patients with schizophrenia. Arch Gen Psychiat 56:21-27

Goff DC, Tsai G, Manoach DS, Coyle JT (1995): Dose-finding trial of D-cycloserine added to neuroleptics for negative symptoms in schizophrenia. Am J Psychiat 152:12131215

Goff DC, Tsai G, Manoach DS, Flood J, Darby DG, Coyle JT (1996): D-cycloserine added to clozapine for patients with schizophrenia. Am J Psychiat 153:1628-1630

Goldman-Rakic PS, Lidow MS, Gallager DW (1990): Overlap of dopaminergic, adrenergic, and serotoninergic receptors and complementarity of their subtypes in primate prefrontal cortex. J Neurosci 10:2125-2138

Goldman-Rakic PS, Selemon LD (1997): Functional and anatomical aspects of prefrontal pathology in schizophrenia [see comments]. Schizophr Bull 23:437-458

Green SM, Johnson NE (1990): Ketamine sedation for pediat- ric procedures: Part 2, Review and implications. Ann Emerg Med 19:1033-1046

Grillon C, Courchesne E, Ameli R, Geyer MA, Braff DL (1990): Increased distractibility in schizophrenic patients. Electrophysiologic and behavioral evidence. Arch Gen Psychiat 47:171-179

Groenewegen HJ, Wright CI, Uylings HB (1997): The anatomical relationships of the prefrontal cortex with limbic structures and the basal ganglia. J Psychopharmacol 11:99-106

Grossberg S (1984): Some normal and abnormal behavioral syndromes due to transmitter gating of opponent processes. Biol Psychiat 19:1075-1118

Grunze H, Greene RW, Moller HJ, Meyer T, Walden J (1998): Lamotrigine may limit pathological excitation in the hippocampus by modulating a transient potassium outward current. Brain Res 791:330-334

Grunze HC, Rainnie DG, Hasselmo ME, Barkai E, Hearn EF, McCarley RW, Greene RW (1996): NMDA-dependent modulation of CA1 local circuit inhibition. J Neurosci 16:2034-2043

Haas DA, Harper DG (1992): Ketamine: a review of its pharmacologic properties and use in ambulatory anesthesia. Anesth Prog 39:61-68

Heresco-Levy U, Javitt DC, Ermilov M, Mordel C, Silipo G, Lichtenstein M (1999): Efficacy of high-dose glycine in the treatment of enduring negative symptoms of schizophrenia. Arch Gen Psychiat 56:29-36

Jakab RL, Goldman-Rakic P, Leranth C (1997): Dual role of substance $\mathrm{P} / \mathrm{GABA}$ axons in cortical neurotransmission: synaptic triads on pyramidal cell spines and basket-like innervation of layer II-III calbindin interneurons in primate prefrontal cortex. Cereb Cortex 7:359-373

Jakab RL, Goldman-Rakic PS (1998): 5-Hydroxytryptamine2A serotonin receptors in the primate cerebral cortex: Possible site of action of hallucinogenic and antipsychotic drugs in pyramidal cell apical dendrites. Proc Nat Acad Sci USA 95:735-740

Javitt DC, Sershen H, Hashim A, Lajtha A (1997): Reversal of phencyclidine-induced hyperactivity by glycine and the glycine uptake inhibitor glycyldodecylamide. Neuropsychopharmacology 17:202-204

Javitt DC, Zukin SR (1991): Recent advances in the phencyclidine model of schizophrenia [see comments]. Am J Psychiat 148:1301-1308

Javitt DC, Zylberman I, Zukin SR, Heresco-Levy U, Lindenmayer JP (1994): Amelioration of negative symptoms in schizophrenia by glycine. Am J Psychiat 151:1234-1236

Jentsch JD, Elsworth JD, Redmond DE, Jr, Roth RH (1997): Phencyclidine increases forebrain monoamine metabolism in rats and monkeys: Modulation by the isomers of HA966. J Neurosci 17:1769-1775

Jentsch JD, Roth RH (1999): The neuropsychopharmacology of phencyclidine: from NMDA receptor hypofunction to the dopamine hypothesis of schizophrenia. Neuropsychopharmacology 20:201-225

Karper LP, Freeman GK, Grillon C, Morgan CA 3rd, Charney DS, Krystal JH (1996): Preliminary evidence of an association between sensorimotor gating and distractibility in psychosis. J Neuropsychiat Clin Neurosci 8:60-66 
Keefe RS, Frescka E, Apter SH, Davidson M, Macaluso JM, Hirschowitz J, Davis KL (1996): Clinical characteristics of Kraepelinian schizophrenia: Replication and extension of previous findings. Am J Psychiat 153:806-811

Kegeles LS, Zea-Ponce Y, Abi-Dargham A, Mann JJ, Laruelle M (1999): Ketamine modulation of amphetamineinduced striatal dopamine release in humans. Biol Psychiat 45:20S

Kehne JH, Baron BM, Carr AA, Chaney SF, Elands J, Feldman DJ, Frank RA, van Giersbergen PL, McCloskey TC, Johnson MP, McCarty DR, Poirot M, Senyah Y, Siegel BW, Widmaier C (1996): Preclinical characterization of the potential of the putative atypical antipsychotic MDL 100,907 as a potent 5-HT2A antagonist with a favorable CNS safety profile. J Pharmacol Exp Ther 277:968-981

Keith VA, Mansbach RS, Geyer MA (1991): Failure of haloperidol to block the effects of phencyclidine and dizocilpine on prepulse inhibition of startle. Biol Psychiat 30:557-566

Komuro H, Rakic P (1993): Modulation of neuronal migration by NMDA receptors. Science 260:95-97

Konig P, Chwatal K, Havelec L, Riedl F, Schubert H, Schultes H (1996): Amantadine versus biperiden: A double-blind study of treatment efficacy in neuroleptic extrapyramidal movement disorders. Neuropsychobiology 33:80-84

Krystal JH, Abi-Dargham A, Laruelle M, Moghaddam B (1999a): Pharmacologic model psychoses. In Charney DS, Nestler E, Bunney BS (ed), Neurobiology of Mental Illness. New York: Oxford University Press, pp 214-224

Krystal JH, Belger A, Abi-Saab W, Moghaddam B, Charney DS, Anand A, Madonick S, D'Souza DC (1999b): Glutamatergic contributions to cognitive dysfunction in schizophrenia. In Harvey PD, Sharma T (eds), Cognitive Functioning in Schizophrenia. London, Oxford University Press

Krystal JH, Belger A, Kirino E, Gore J, McCarthy G (1998a): Ketamine effects on the cortical processing of novelty in humans assessed with FMRI. Soc Neurosci Abst 24:259 (abstract \#104.7)

Krystal JH, Bennett A, Abi-Saab D, Belger A, Karper LP, D'Souza DC, Lipschitz D, Abi-Dargham A, Charney DS (1999c): Dissociation of ketamine effects on rule acquisition and rule implementation: Possible relevance to NMDA receptor contributions to executive cognitive functions. Biol Psychiat, in press

Krystal JH, Bennett A, Bremner JD, Southwick S, Charney DS (1995): Toward a cognitive neuroscience of dissociation and altered memory functions in post-traumatic stress disorder. In Friedman MJ, Charney DS, Deutch AY (eds), Neurobiological and Clinical Consequences of Stress: From Normal Adaptation to PTSD. New York: Raven, pp 239-269

Krystal JH, D'Souza DC, Karper LP, Bennett A, AbiDargham A, Abi-Saab D, Bowers MB Jr, Jatlow P, Heninger GR, Charney DS (1999d): Interactive effects of subanesthetic ketamine and haloperidol. Psychopharmacology 145:193-204

Krystal JH, D'Souza DC, Petrakis IL, Belger A, Berman R, Charney DS, Abi-Saab W, Madonick S (1999e): NMDA agonists and antagonists as probes of glutamatergic dysfunction and pharmacotherapies for neuropsychiatric disorders. Harv Rev Psychiat 7:125-133

Krystal JH, Karper LP, Bennett A, D'Souza DC, AbiDargham A, Morrissey K, Abi-Saab D, Bremner JD, Bowers MB Jr, Suckow RF, Stetson P, Heninger GR, Charney DS (1998b): Interactive effects of subanesthetic ketamine and subhypnotic lorazepam in humans. Psychopharmacology 135:213-229

Krystal JH, Karper LP, D'Souza DC, Belger A, Abi-Saab D, White J, Charney DS, Grillon C (1999f): Disruption of human sensorimotor gating by subanesthetic ketamine. in preparation

Krystal JH, Karper LP, Seibyl JP, Freeman GK, Delaney R, Bremner JD, Heninger GR, Bowers MB Jr, Charney DS (1994a): Subanesthetic effects of the noncompetitive NMDA antagonist, ketamine, in humans. Psychotomimetic, perceptual, cognitive, and neuroendocrine responses. Arch Gen Psychiat 51:199-214

Krystal JH, Moghaddam B, Breier A, Goldman-Rakic P, McElvey J (1998c): Glutamate, dopamine, the frontal cortex, and schizophrenia. Biol Psychiat 43:60S

Krystal JH, Webb E, Cooney N, Kranzler HR, Charney DS (1994b): Specificity of ethanol-like effects elicited by serotonergic and noradrenergic mechanisms. Arch Gen Psychiat 51:898-911

Kurumaji A, McCulloch J (1990): Effects of unilateral intrahippocampal injection of MK-801 upon local cerebral glucose utilisation in conscious rats. Brain Res 518:342-346

Lahti AC, Holcomb HH, Medoff DR, Tamminga CA (1995a): Ketamine activates psychosis and alters limbic blood flow in schizophrenia. Neuroreport 6:869-872

Lahti AC, Koffel B, LaPorte D, Tamminga CA (1995b): Subanesthetic doses of ketamine stimulate psychosis in schizophrenia. Neuropsychopharmacology 13:9-19

Laruelle M, Abi-Dargham A, van Dyck CH, Gil R, D'Souza $\mathrm{CD}$, Erdos J, McCance E, Rosenblatt W, Fingado C, Zoghbi SS, Baldwin RM, Seibyl JP, Krystal JH, Charney DS, Innis RB (1996): Single photon emission computerized tomography imaging of amphetamine-induced dopamine release in drug-free schizophrenic subjects. Proc Nat Acad Sci USA 93:9235-9240

Leiderman E, Zylberman I, Zukin SR, Cooper TB, Javitt DC (1996): Preliminary investigation of high-dose oral glycine on serum levels and negative symptoms in schizophrenia: An open-label trial [see comments]. Biol Psychiat 39:213-215

Lejeune F, Gobert A, Rivet JM, Millan MJ (1994): Blockade of transmission at NMDA receptors facilitates the electrical and synthetic activity of ascending serotoninergic neurones. Brain Res 656:427-431

Lévesque D, Diaz D, Pilon C, Martres M-P, Giros B, Souil E, Schott D, Morgat J-L, Schwartz J-C, Sokoloff P (1992): Identification, characterization, and localization of the dopamine $\mathrm{D}_{3}$ receptor in rat brain using $7-\left[{ }^{3} \mathrm{H}\right]$ hydroxy$N$, N-di- n-propyl-2-aminotetralin. Proc Natl Acad Sci USA 89:8155-8159

Liddle PF, Morris DL (1991): Schizophrenic syndromes and frontal lobe performance. Br J Psychiat 158:340-345

Lieberman JA, Kane JM, Alvir J (1987a): Provocative tests with psychostimulant drugs in schizophrenia. Psychopharmacology 91:415-433 
Lindefors N, Ballarin M, Ernfors P, Falkenberg T, Persson H (1992): Stimulation of glutamate receptors increases expression of brain-derived neurotrophic factor mRNA in rat hippocampus. Ann NY Acad Sci 648:296-299

Lindefors N, Barati S, O'Connor WT (1997): Differential effects of single and repeated ketamine administration on dopamine, serotonin, and GABA transmission in rat medial prefrontal cortex. Brain Res 759:205-212

Lipschitz DS, D'Souza DC, White JA, Charney DS, Krystal JH (1997): Clozapine blockade of ketamine effects in healthy subjects. Biol Psychiat 41:23S

Lipton SA, Kater SB (1989): Neurotransmitter regulation of neuronal outgrowth, plasticity and survival. TINS $12: 265-270$

Lisman JE, Fellous JM, Wang XJ (1998): A role for NMDAreceptor channels in working memory. Nat Neurosci 1:273-276

Lubke J, Markram H, Frotscher M, Sakmann B (1996): Frequency and dendritic distribution of autapses established by layer 5 pyramidal neurons in the developing rat neocortex: Comparison with synaptic innervation of adjacent neurons of the same class. J Neurosci 16:32093218

Luby ED, Cohen BD, Rosenbaum G, Gottlieb JS, Kelley R (1959): Study of a new schizophrenomimetic drug-Sernyl. Arch Neurol Psychiat 81:363-369

Madison DV, Malenka RC, Nicoll RA (1991): Mechanisms underlying long-term potentiation of synaptic transmission. Ann Rev Neurosci 14:379-397

Magistretti PJ, Pellerin L (1997): Metabolic coupling during activation. A cellular view. Adv Exp Med Biol 413:161-166

Malhotra AK, Adler CM, Kennison SD, Elman I, Pickar D, Breier A (1997): Clozapine blunts N-methyl-D-aspartate antagonist-induced psychosis: A study with ketamine. Biol Psychiat 42:664-668

Malhotra AK, Pinals DA, Weingartner H, Sirocco K, Missar CD, Pickar D, Breier A (1996): NMDA receptor function and human cognition: The effects of ketamine in healthy volunteers. Neuropsychopharmacology 14:301-307

Marini AM, Rabin SJ, Lipsky RH, Mocchetti I (1998): Activity-dependent release of brain-derived neurotrophic factor underlies the neuroprotective effect of N-methylD-aspartate. J Biol Chem 273:29394-29399

Martin P, Waters N, Carlsson A, Carlsson ML (1997): The apparent antipsychotic action of the 5-HT2a receptor antagonist M100907 in a mouse model of schizophrenia is counteracted by ritanserin. J Neural Transm 104:561-564

Martin P, Waters N, Schmidt CJ, Carlsson A, Carlsson ML (1998): Rodent data and general hypothesis: Antipsychotic action exerted through 5-HT2A receptor antagonism is dependent on increased serotonergic tone. J Neural Transm 105:365-396

Meltzer HY (1997): Treatment-resistant schizophrenia-The role of clozapine. Curr Med Res Opin 14:1-20

Miller CH, Hummer M, Pycha R, Fleischhacker WW (1992): The effect of ritanserin on treatment-resistant neuroleptic-induced akathisia: Case reports. Prog Neuropsychopharmacol Biol Psychiat 16:247-251

Moghaddam B, Adams B, Verma A, Daly D (1997): Activation of glutamatergic neurotransmission by ketamine: A novel step in the pathway from NMDA receptor blockade to dopaminergic and cognitive disruptions associated with the prefrontal cortex. J Neurosci 17:2921-2927

Moghaddam B, Adams BW (1998): Reversal of phencyclidine effects by a group II metabotropic glutamate receptor agonist in rats. Science 281:1349-1352

Nehls DG, Kurumaji A, Park CK, McCulloch J (1988): Differential effects of competitive and noncompetitive $\mathrm{N}$-methyl-D-aspartate antagonists on glucose use in the limbic system. Neurosci Lett 91:204-210

Newcomer JW, Farber NB, Jevtovic-Todorovic V, Selke G, Kelly Melson A, Hershey T, Craft S, Olney JW (1999): Ketamine-induced NMDA receptor hypofunction as model of memory impairment and psychosis. Neuropsychopharmacology 20:106-118

Offord SJ (1998): M100907, a highly selective 5-HT2A antagonist for treatment of schizophrenia: Early indication of safety and clinical activity in schizophrenic patients. Poster presented at the 21st Collegium International Neuro-Psychopharmacologium (CINP) Congress, Glasgow, Scotland

Olney JW, Farber NB (1995a): Glutamate receptor dysfunction and schizophrenia [see comments]. Arch Gen Psychiat 52:998-1007

Olney JW, Farber NB (1995b): NMDA antagonists as neurotherapeutic drugs, psychotogens, neurotoxins, and research tools for studying schizophrenia. Neuropsychopharmacology 13:335-345

Øye I, Paulsen O, Maurset A (1992): Effects of ketamine on sensory perception: Evidence for a role of N-methyl-Daspartate receptors. J Pharmacol Exp Ther 260:1209-1213

Patel TR, McCulloch J (1995): AMPA receptor antagonism attenuates MK-801-induced hypermetabolism in the posterior cingulate cortex. Brain Res 686:254-258

Raedler TJ, Knable MB, Weinberger DR (1998): Schizophrenia as a developmental disorder of the cerebral cortex. Curr Opin Neurobiol 8:157-161

Rajkowska G, Selemon LD, Goldman-Rakic PS (1998): Neuronal and glial somal size in the prefrontal cortex: A postmortem morphometric study of schizophrenia and Huntington's disease. Arch Gen Psychiat 55:215-224

Rakic P, Bourgeois JP, Goldman-Rakic PS (1994): Synaptic development of the cerebral cortex: Implications for learning, memory, and mental illness. Prog Brain Res 102:227-243

Reich DL, Silvay G (1989): Ketamine: An update on the first twenty-five years of clinical experience. Can J Anaesth 36:186-197

Rothman SM, Olney JW (1987): Excitotoxicity and the NMDA receptor. TINS 10:299-302

Schiller J, Schiller Y, Clapham DE (1998): NMDA receptors amplify calcium influx into dendritic spines during associative pre- and postsynaptic activation. Nat Neurosci 1:114-118

Schmidt CJ, Fadayel GM (1996): Regional effects of MK-801 on dopamine release: Effects of competitive NMDA or 5-HT2A receptor blockade. J Pharmacol Exp Ther 277:1541-1549

Segal M (1995): Imaging of calcium variations in living den- 
dritic spines of cultured rat hippocampal neurons. J Physiol 486:283-295

Selemon LD, Rajkowska G, Goldman-Rakic PS (1998): Elevated neuronal density in prefrontal area 46 in brains from schizophrenic patients: Application of a threedimensional, stereologic counting method. J Comp Neurol 392:402-412

Sibson NR, Dhankhar A, Mason GF, Behar KL, Rothman DL, Shulman RG (1997): In vivo 13C NMR measurements of cerebral glutamine synthesis as evidence for glutamateglutamine cycling. Proc Nat Acad Sci USA 94:2699-2704

Sibson NR, Dhankhar A, Mason GF, Rothman DL, Behar KL, Shulman RG (1998): Stoichiometric coupling of brain glucose metabolism and glutamatergic neuronal activity. Proc Nat Acad Sci USA 95:316-321

Stefani A, Spadoni F, Siniscalchi A, Bernardi G (1996): Lamotrigine inhibits $\mathrm{Ca} 2+$ currents in cortical neurons: Functional implications. Eur J Pharmacol 307:113-116

Swerdlow NR, Geyer MA (1998): Using an animal model of deficient sensorimotor gating to study the pathophysiology and new treatments of schizophrenia. Schizophr Bull 24:285-301

Tamminga CA, Tanimoto K, Kuo S, Chase TN, Contreras PC, Rice KC, Jackson AE, O'Donohue TL (1987): PCPinduced alterations in cerebral glucose utilization in rat brain: Blockade by metaphit, a PCP-receptor-acylating agent. Synapse 1:497-504

Tamminga CA, Thaker GK, Buchanan R, Kirkpatrick B, Alphs LD, Chase TN, Carpenter WT (1992): Limbic system abnormalities identified in schizophrenia using positron emission tomography with fluorodeoxyglucose and neocortical alterations with deficit syndrome. Arch Gen Psychiat 49:522-530

Tsai G, Yang P, Chung LC, Lange N, Coyle J (1998): D-serine added to antipsychotics for the treatment of schizophrenia. Biol Psychiat 44

Umbricht D, Vollenweider FX, Javitt D, Schmidt L, Hell D (1999): Effects of ketamine on preattentive and attention-dependent auditory event-related potentials (ERP). Schizophr Res 36:260

Van Tol HHM, Bunzow JR, Guan H-C, Sunahara RK, Seeman P, Niznik HB, Civelli O (1991): Cloning of the gene for a human dopamine $\mathrm{D}_{4}$ receptor with high affinity for the antipsychotic clozapine. Nature 350:610-614

Varty GB, Bakshi VP, Geyer MA (1999): M100907, a serotonin 5-HT2A receptor antagonist and putative antipsychotic blocks dizocilpine-induced prepulse inhibition deficits in Sprague-Dawley and Wistar rats. Neuropsychopharmacology 29:311-321

Verma A, Moghaddam B (1996): NMDA receptor antagonists impair prefrontal cortex function as assessed via spatial delayed alternation performance in rats: modulation by dopamine. J Neurosci 16:373-379

Waldmeier PC, Martin P, Stocklin K, Portet C, Schmutz M (1996): Effect of carbamazepine, oxcarbazepine, and lamotrigine on the increase in extracellular glutamate elicited by veratridine in rat cortex and striatum. Naunyn-Schmiedebergs Arch Pharmacol 354:164-172

Wang SJ, Huang CC, Hsu KS, Tsai JJ, Gean PW (1996): Inhibition of N-type calcium currents by lamotrigine in rat amygdalar neurones. Neuroreport 7:3037-3040

Wang XJ, Buzsaki G (1996): Gamma oscillation by synaptic inhibition in a hippocampal interneuronal network model. J Neurosci 16:6402-6413

Weinberger DR, Berman KF (1996): Prefrontal function in schizophrenia: Confounds and controversies. Philosoph Trans Roy Soc Lond-Series B: Biolog Sci 351:1495-1503

White PF, Way WL, Trevor AJ (1982): Ketamine-Its pharmacology and therapeutic uses. Anesthesiology 56:119136

Wiesel FA, Nordstrom AL, Farde L, Eriksson B (1994): An open clinical and biochemical study of ritanserin in acute patients with schizophrenia. Psychopharmacology 114:31-38

Williams GV, Goldman-Rakic PS (1995): Modulation of memory fields by dopamine D1 receptors in prefrontal cortex [see comments]. Nature 376:572-575

Wilson FA, O'Scalaidhe SP, Goldman-Rakic PS (1994): Functional synergism between putative gamma-aminobutyrate-containing neurons and pyramidal neurons in prefrontal cortex. Proc Nat Acad Sci USA 91:4009-4013

Woo TU, Whitehead RE, Melchitzky DS, Lewis DA (1998): A subclass of prefrontal gamma-aminobutyric acid axon terminals are selectively altered in schizophrenia. Proc Nat Acad Sci USA 95:5341-5346

Yuste R, Majewska A, Cash SS, Denk W (1999): Mechanisms of calcium influx into hippocampal spines: Heterogeneity among spines, coincidence detection by NMDA receptors, and optical quantal analysis. J Neurosci 196:1976-1987

Zukin SR, Zukin RS (1979): Specific $\left[{ }^{3} \mathrm{H}\right]$ phencyclidine binding in rat central nervous system. Proc Nat Acad Sci USA 76:5372-5376 